\title{
Effective use of Budgeting as a Tool Towards Financial Management in Schools in Lejweleputswa District
}

MOSALA, George | MOFOLO, Malefetsane A.

\section{Abstract}

In South Africa, public schools are I expected to do their utmost to improve the quality of education. However, a notion exists that for a school to improve the quality of education, enough resources should be available. Although this notion is critical, it is the argument of this article that school financial management capacity is also a challenge in most of the public schools in South Africa. In this regard, the study, attempted to establish the effectiveness of budgeting in the public schools to ensure that quality education is promoted; and whether parents in the SGBs are knowledgeable enough to prepare the school budgets. In order to realise these objectives, an empirical study was undertaken, following the literature study which formed its basis. The findings confirmed that knowledge of budgeting as an aspect of financial management is lacking or inadequate in some schools. This is demonstrated by the level of contradictions of schools in meeting their basic needs, such as procurement of books and other materials. Consequently, it was recommended that capacity building endeavours should focus on financial planning, communication, decision-making, organising, delegating, coordinating, leading, and controlling in order to bring about effective financial management in public schools.

Keywords: Budgeting, Financial management, School Management Teams (SMTs), School Governing Bodies (SGBs), Quality education, Prioritise 


\section{Introduction}

The South African School's Act (Act No. 84 of 1996) (SASA) imposes a responsibility on all public schools to do their utmost to improve the quality of education. However, Gorton and Alston (2012:139) indicate that for a school to improve the quality of education, enough resources should be available. This contention arises from the fact that the funds which government apportion to schools are not sufficient to meet all educational needs (Botha, 2013:123), particularly in the so-called "no-fee schools."

Furthermore, Mestry (2013:175) reveals that schools are struggling to implement the budget in the firts term because the provincial departments of education deposit the money for the operating costs into schools' banking accounts rather late in the year, as the result, schools experience serious financial setbacks.

Although all the above-mentioned challanges could be seen as factors that hinder or delay the schools to improve quality of education, particularly in the township schools, it is the view of this article that school financial management capacity is also a challenge in most of the public schools in South Africa. The issue of illiteracy among school governing body (SGB) members, in particular, parent-governors has been regarded as a constraining factor for schools to successfully manage their funds (Maile, 2002, cited in Xaba, 2011:202). Therefore, the lack of financial management skills in some public schools is a cause of great concern (Xaba \& Ngubane, 2010:147).

Xaba's (2011:207) research findings, indicate that in some schools there is a tendency of SGBs to deviate from the budget due to the competing views of the governors. This tendancy gives an impression that some shools' budgets are compiled without prior planning. The budget should be proactively prepared in a planned, accurate and surveyable manner (Botha, 2013:196) in order to achieve educational objectives.

Section 38 (1) of the SASA requires that SGBs of public schools to prepare an annual budget according to guidelines determined by the Education Member of the Executive Council (MEC) in the province. Therefore, since the budget should be informed by the needs of the school, the SGB should work together with school management team (SMT), whose link is the principal as a member of both structures, to prepare school budgets in order to ensure that there is enough fund to meet school educational plans.

To draw attention to the contentions raised in this article, an investigation to the selected schools in the Lejweleputswa District of Education in the Free State was conducted in order to establish the effectiveness of budgeting in the public schools to ensure that 
quality education is promoted; and whether parents in the SGBs are knowledgeable enough to prepare the school budgets. These objectives are regarded in this article as critical to be pursued in order to bring another pespective to the discourse.

\section{The Definition and Theoretical Perspective of Financial Management in Schools}

According to Mestry and Bisschoff (2009: 2), financial management refers to the performance of management actions on the financial aspects of a school with the aim of achieving quality education. On the other hand, Watson (2000:47) and Saye (1998:8) point out that financial management refers to activities that should be undertaken by SGB and SMT, which include handling of funds, purchasing, payment of services, the expending of funds, making inventories, auditing, financial reporting, and maintenance of property, as well as budget management.

On the issue of budget management, Niemann (2002) cited in Xaba and Ngubane (2010:143), indicates that budgeting deals with planning of school finances. In other words, budget management implies that it is neither wise nor prudent to spend money until the SGB has determined prioritise based on the school's development plan. This suggests that budget management is a sensitive process which requires SMTs and SGBs to prioritise the needs of the school first, based on the broad picture of the school's total income, and then approve it for implementation.

However, according to Section 38 of the SASA, before a budget is approved by the SGB must be presented to a general meeting of parents on at least 30 days' notice, for consideration and approved by a majority of parents present and voting. Once the budget has been approved, monthly budgetary accounting procedure should begin in order to ensure that the funds are spent according to the approved budget.

In this regard, the school financial clerk should present on monthly basis the financial records to the SGB in order to determine corrective measures needed to the budget; and at times amendments needed. If amendments or adjustments to the budget are needed during the financial year, such adjustments should be done in consideration of prioritise and the endorsement of the SGBs (Levacic, 1995:101).

Some reasons for adjusting or amending a budget may result from government subsidy, number of learners enrolled and the level of exemptions to pay school fees before 
the 31st January of the following year (Department of Education, 2002: 53), or perhaps inability to raise enough funds as it was innitially planned.

\section{The Financial Management Tasks of SMTs and SGBs}

As shown earlier in the introduction, the responsibility of running the finances of the public school rests with the SGB. However, in carrying its financial tasks the SGB should work together with the SMT to ensure that management tasks of the school are jointly related to and intertwined with educational goals. Hence, Vander Westhuizen (1996:52) and Dean (2000:75) aptly state that various management tasks in schools require the application of positive standards, and SGBs, as well as SMTs are required to execute a variety and multiplicity of functions, such as planning, communication, decision-making, organising, delegating, co-ordinating, leading, and controlling of school funds.

Therefore, budgeting as a management task is incorporated in all the duties and activities performed by the SMTs and SGBs as per some clauses in Section 20 and 21 of the SASA, since the functional responsibilities of the two structures (SGB and SMT) are coherently concomitant. Consequently, in the next sub-sections, these functions are discussed in order to increase the understanding.

\section{Financial Planning}

According to Makhubela (2005:16), it would be difficult to meet the needs of the school if the correct financial planning procedures are not followed. In this regard, school's budget must be prepared according to provincial guidelines (South African Scools Act, 1996:24), in order for the school to attain its objectives and goals. Planning of institutional objectives and goals forms an important part of financial managerial tasks of a school (Van der Westhuizen, 1996:37; Fidler, 1997:1).

Therefore, financial planning should include the determination of the school's objectives and activities, as well as financial policies and financial procedures (Knight 1997:8; Blandford, 1997:86; Reason \& Bradbury, 2001:318). The lack of planning the day to day activities of the school can result in waste and inefficiency in the management of the school's resources, hence all school activities should be guided and influenced by a budget.

Watson (2000:46-49) indicates that the main task in preparing a financial plan is to provide a summary of the information contained in the relevant policies. The task of 
preparation ensures that the stakeholders use the policy programme relationships and priorities as the starting point for programme planning and budgeting. The plan for implementation of a school budget entails what is going to be done, who is going to do it, how often, with what and where.

In short, a budget is an estimate of proposed income and expenditure. It serves as a planning device, a managerial tool, and a basis for reports (Harris, 1996:83; Correia, Flynn, Uliana \& Wormald, 2000:763; Esterhuyse, Horn \& Liebenberg, 2005:127).

\section{Communication of budgeting}

Budgeting or financial planning has to be an issue that involves parents, learners and educators of a school. It can only be attained through proper discussion by all stakeholders. A mutual exchange of ideas and interpretation of the information, therefore, form an important aspect of school budgeting (Clark \& Lacey, 1997:39; Dean, 2000:87). Coleman (1998:4-5) and Watson (2000:78) state that good communication of financial management matters requires consciousness, clarity, simplicity, accuracy, direction and common sense from both SMTs and SGBs.

Internal communication concerning school financial management matters is important to ensure that all internal stakeholders know when to make their submissions and how to spend the funds allocated to them (Human, Llewellyn, Eksteen \& Miller, 2005:151). All of these matters should be clearly stipulated in the financial policy of the school (Blandford, 1997:71; Dodd \& Konza, 2002:60-61). Regular feedback on spending will ensure that all internal stakeholders remain within their budget limits. The budget, in conjunction with the financial policy of the school, is the most important medium for relaying messages related to school financial management to the internal stakeholders.

Communication is, however, not limited to the budget, but needs to be used to create financial structure, delegate and co-ordinate, establish relationships, motivate learners and staff, exercise control and extend relationships externally (Clark \& Lacey, 1997:40; Van Schalkwyk, 1999:5; Esterhuyse et al., 2005:67).

The main purpose of communicating effectively with the external stakeholders is not primarily to obtain funds for the school. Although financial support is important, it is not the only support the school needs. The feedback that the external stakeholders receive from the school appears to be of strategic use for building positive attitudes. 
The school principal's communication task involves reporting to the external stakeholders about particulars on the budget, school fees, and the actual income and expenditure for the following year (Herring, 1997:85; Van Schalkwyk, 1999:32). Regular reporting regarding financial management functions at the school is the principals' responsibility, because of his or her being the accounting officer of the school.

Reporting on the financial position of a school to external stakeholders should be kept simple. Visual diagrams are always important for assisting external stakeholders without any accounting experience to gain insight into the finances of the school (Van Schalkwyk, 1999:7; Laws, Harper \& Marcus, 2003:251).

Schools may also communicate through; prospectuses, brochures and flyers; newsletters and invitations; word of mouth; media, local press and television; and group promotion.

\section{Decision making regarding school finances}

The SMTs and SGBs have to make decisions concerning school budgeting (Starrat 1996:5; Coleman, 1998:136). Decision-making entails inclusive participation and consultation with all stakeholders of a school, thus creating a healthy relationship among the educators, parents, learners and the community (Dodd \& Konza, 2002:150).

Many schools attempt transparency in their management systems by publishing plans or diagrams in school newsletters and in communications with parents and educators, in order to indicate formal management structures. This is an attempt to illustrate official decision-making routes, which serves it as an explanation of the way individuals should take in order to discuss problems and possibilities within the structure of the school. This hierarchical structure enables the flow of communication within a school, and allows for effective consultation processes (Levacic, 1995:55; Starrat, 1996:7).

In all educational institutions, decision making and communication are closely linked, especially where the SMTs and SGBs of the school are committed to open decision-making and where they believe that all individuals should take part in decision-making (Horne $\&$ Brown, 1997:18; Bisschoff, du Plessis \& Smith, 2004:51).

Everard and Morris (1996:39) contend on the sensitive balance between supplying too much information, asking for too much consultation from the SGBs and SMTs and making uninformed decisions without any prior consultation. Whichever balance is attained, it should be based on the management philosophy of the SMTs in a school and enabling 
them to disseminate information. In theory this is an effective way to be managing the decision-making processes of a school (Everard \& Morris, 1996:40).

The correct decision-making is imperative to school budgeting. As a result, budgeting activities could be carried out effectively through decision-making and delegation (Bisschoff et al., 2004:53; Esterhuyse et al., 2005:120).

\section{Delegation of financial tasks}

Delegation is part of organising the financial management of a school, since a specific task is given to a specific staff member through delegation (Gold \& Evans, 1998:80; Esterhuyse et al., 2005:20). Since financial management tasks cannot be delegated randomly, the chairperson of the SGBs should consider the background and circumstances of individual staff members beforehand. Should the chairperson have personnel at his or her disposal with some commercial knowledge, he or she should delegate mainly financial tasks to them. Should these staff members not be available, the matter may become more complex, since a search must be made for personnel with the right expertise (Knight, 1995:3-6; Horne \& Brown, 1997:18).

Delegation ensures that the task of organising takes place in an orderly manner, which requires the school principal to coordinate all activities. It is the duty of the SGBs and SMTs to build a healthy and harmonious bond among educators, parents and learners to serve as one big family in an effort to organise activities in school (Blandford, 1997:41; Gann, 1998:72).

\section{Financial organising}

The activity of organising involves devising an institutional structure, delegating duties and establishing relationships. Van der Westhuizen (1996:161), Gallagher, Bagin and Kindred (1997:61), Sallis and Jones (2002:24) agree that organising is the creation of a formal system of authority by which components are clarified and delegated for the purpose of education. Such functions are executed in order to develop budgeting plans and establish coordination with all school stakeholders in order for goals to be achieved effectively (Reason \& Bradbury, 2001:329). 


\section{Financial coordination}

Coordination is the synchronisation of all actions, means and techniques within the school (Herring, 1997:18). The financial committee of the SGBs should ensure that all actions, means and techniques related to school finance are coordinated. In organising school finances, co-ordination should involve the synchronisation of all the administrative and accounting activities in the school, from the mission statement to the final financial statements of the school's activities (Esterhuyse et al., 2005:120). The financial committee of the SGB should draw up the school's financial policy and show firm leadership by clearly indicating the functions of all those involved in the school's finance (Horne \& Brown 1997:66).

Coordination ensures performance of the activities of SMTs members, which leads to the promotion of team spirit and mutual understanding at schools (Latchem \& Hanna, 2001:78). It is also important for the SMTs to coordinate school activities and thus achieve positive results required by all stakeholders. Meaningful coordination of budgeting activities requires committed leadership by the SMTs in order to build trust and confidence of parents, educators and learners.

\section{Financial leadership}

Knight (1997:104) and Watson (2000:6-8) declare that being a good leader and manager of a school is more demanding than excelling at the work you are responsible and accountable for. David, Bryd and McIntyre (1999:168), Watson (2000:93-97), Latchem and Hanna (2001:53) further maintain that a good leader should conscientiously manage and execute school budgeting activities. The SMTs should also heed the fact that leadership is exercised in the performance of school tasks, mainly based on the control of budgeting functions of a school (Smith \& Piele, 1997:15; Coleman 1998:157).

With proper control, planning and organising, the SGBs and SMTs could achieve desired output and, together with the supplementary factor of competent leadership, excellent results can be attained. A school principal with noticeable leadership qualities should be able to persuade his/her staff to accept his/her leadership style (Sallis \& Jones, 2002:27).

The importance of a flourishing school and a competent principal is found in healthy human relations, trustworthy advice, commendable leadership and a two-way 
communication between the principal and the staff (Everard \& Morris 1996:34; Frost, Durrant, Head \& Holden, 2000:128; Esterhuyse et al., 2005:118).

\section{Financial control}

Budgetary control concerns itself with total costs for each department, where each variance is the responsibility of the official in charge of the department in which it arises. He/she must therefore explain the variance and take action to stop its recurrence. Budget control is a system of controlling costs which includes the preparation of budgets, coordinating actual performance budget and acting upon results to achieve maximum output (Daft, 1995:545; Correia, et al., 2000:765).

Differences between budgeted and actual performance are termed variances. These variances will be useful as a spur to immediate remedial action if actual performance is below expectation. Budgeting starts with a given or forecast finding allocation and seeks to divide all the total resources available in a detailed breakdown between the various departments that the school manages.

It should therefore be apparent that a budget can only be prepared accurately after considering the planned activities of each department for the coming year (Busher, Harris \& Wise, 2000:18). The plans must include all activities of the school and should take into account any rules imposed by the government. Control cannot be considered in isolation from funding levels since it is conceivable that costed plans may exceed the available funding (Gann, 1998:23; Dean, 2000:8; Esterhuyse et al., 2005:118). In such cases, activities will have to be rethought until final agreed budgets are arrived at. This is a sensitive process that will require a school to decide upon priorities (Daft, 1995:546).

Budget control therefore implies the drafting of an annual budget, which will be uniquely adapted to the specific situation, and circumstances of each school. A budget does not control anything. People control by using a budget. The lack of sufficient budgetary control, acceptable conditions for financing schools and legal connections to educational programmes in most school budgets, denies any effective means of supporting good programmes and weeding out bad ones (Harris, 1996:75-77). 


\section{The Policy Context of Financial Management in South African Schools}

Although, some policy stipulations have been referred to in the previous sections of this discussions, it is proper that in this section the policy context of financial management in South African schools is given attention.

Section 21 of the SASA stipulates that to purchase textbooks, educational materials or equipment for the school, are among other functions allocated to the SGBs. In this regard, as mentioned earlier in this article, in order for the SGB to carry out its functions efficiently and effectively, a budget must be prepared each year, according to guidelines determined by the Head of the Department (HOD), which indicates the estimated income and expenditure of the school for the following financial year (Section 38).

Equally important, Section 19 of SASA stipulates that the HOD should provide introductory training for newly elected SGBs to enable them to perform their functions. Afterward, they should be provided with continuous training in order to promote the effective performance of their functions or to enable them to assume additional functions. The continuous training of SGBs is very critical, particularly when considering the following opinion expressed by an SGB parent in Xaba's (2011:207) research report:

We are experiencing problems with regard to finances. We have not reached a stage where we are really sure that we have received full information, skills and knowledge with regard to school finances. I am not satisfied with the way we have been trained. The training took three days which was far too short for such a huge responsibility.

When analysing this opinion, it becomes evident that continuous training is fundamental for the SGB members, particularly on sections of the SASA, which relate to school financial management.

As a measure of managing school fees, Section 37 of the SASA states that the SGBs must establish a school fund and administer it in accordance with directions issued by the HOD. This includes the opening and maintenance of a bank account in the name of a school. In the same manner, Section 42 enjoins SGBs to keep records of funds received and spent by the school, and not later than three months after the end of each financial year, draw up annual financial statements as per the guidelines determined by the MEC.

In order to ensure accountability, Section 43 instructs SGBs to appoint an independent person qualified to audit the records and financial statements each year, and submit to 
the HOD within 6 months after the end of the financial year, a copy of the audited financial statements.

In the final analysis, it becomes clear that training is critical for the SGB members to have the necessary financial management skills.

\section{METHOD}

\section{Approaches}

The research approaches considered to be relevant for this study were qualitative and quantitative methods, which normally are called mix-methods or triangulation. In this regard, qualitative method was viewed as appropriate for this study because it becomes possible to measure the reactions of many people to a limited set of questions, thus facilitating direct comparisons between people (Best \& Kahn, 2003:241; Radebe, 1995:50), in this case, the responses of principals, SMTs, educators, financial clerks, and parents in SGBs.

On the other hand, quantitative method was also seen to be suitable for this study, since numbers are important at all levels of measurement in a research. Therefore, it was assumed that quantitative and qualitative methods would complement each other in bringing about a meaningful research finding (Bryman \& Cramer, 1999:2).

Earlier discussions in this article showed that the focus of this study is on public schools, as it was discovered that they are facing serious financial management challenges. Therefore, the participants who formed the unit of analysis of this study were drawn from town and township public schools in Lejweleputswa District of Education. The idea was to establish the effectiveness of budgeting in the public schools to ensure that quality education is promoted, and whether parents in SGBs are knowledgeable enough to prepare the budget.

\section{Participant selection}

The participants who formed the sample of this study were drawn from the population of 80 principals from both primary and secondary schools, 160 educators from both primary and secondary schools, 160 SMTs from both primary and secondary schools, 80 school financial clerks of primary and secondary schools, 160 parents serving in SGBs of primary and secondary schools. This information is presented in Table 1 below. 
Table 1: Research population

\begin{tabular}{|l|c|c|c|}
\hline \multicolumn{1}{|c|}{ Population } & Primary School & Secondary School & Total \\
\hline Principals & 40 & 40 & 80 \\
\hline SMTs & 80 & 80 & 160 \\
\hline Educators & 80 & 80 & 160 \\
\hline Parents in SGBs & 80 & 80 & 160 \\
\hline Financial clerk & 40 & 40 & 80 \\
\hline TOTAL & $\mathbf{3 2 0}$ & $\mathbf{3 2 0}$ & $\mathbf{6 4 0}$ \\
\hline
\end{tabular}

Table 1 shows the population size of 640 , from which the sample was drawn. The sample in this study comprises 473 units of analysis. Tables 2 and 3 below represent sample, which was drawn from the population displayed in Table 1 above.

Table 2: Participants in town Secondary and Primary schools

\begin{tabular}{|c|c|c|c|c|c|c|}
\hline $\begin{array}{c}\text { Secondary } \\
\text { \& } \\
\text { Primary Schools }\end{array}$ & Principals & HODs & Educators & $\begin{array}{c}\text { Financial clerks } \\
\text { or secretaries }\end{array}$ & $\begin{array}{c}\text { Parents } \\
\text { in SGBs }\end{array}$ & Total \\
\hline & 33 & 60 & 71 & 29 & 62 & 255 \\
\hline
\end{tabular}

Table 3: Participants in township Secondary and Primary schools

\begin{tabular}{|c|l|c|c|c|c|c|}
\hline $\begin{array}{c}\text { Secondary \& } \\
\text { primary schools }\end{array}$ & Principals & HODs & Educators & $\begin{array}{c}\text { Financial clerks } \\
\text { or secretaries }\end{array}$ & $\begin{array}{c}\text { Parents } \\
\text { in SGBs }\end{array}$ & Total \\
\hline & 22 & 44 & 59 & 15 & 78 & 218 \\
\hline
\end{tabular}

As shown above that the sample size of this study comprised of 473 participants, therefore, 473 questionnaires were distributed to them. From Tables 2 and 3, the statistical 
information shows that 55 questionnaires were distributed to principals, 104 to SMTs, 130 to educators, 44 to school financial clerks, 140 to parents in SGBs. Out of 473 questionnaires, 65 were not completed by town schools, while 102 were not completed by township schools. In other words, the total of 167 questionnaires were not completed, while 306 of them were completed, which constituted the response rate of $65 \%$.

\section{Sampling strategy and Data collection methods}

Purposeful sampling strategy was used to select the sample that is presented in Tables 2 and 3 above. The participants were perceived in this study as well informed and experienced in budgeting in their schools. Therefore, the sites where the research was conducted were selected primary and secondary schools both from towns and townships in Lejweleputswa district in the Free State.

The instrument used to collect data in this study was the questionnaire. The questionnaire was the instrument regarded to be suitable since it accommodates qualitative and quantitative approaches, by posing open and closed research questions simultaneously in an instrument.

\section{Data analysis}

The collected data was analysed using descriptive statistics, by applying mathematical procedures that serve to simplify, summarise, and organise relatively large amounts of numerical data. This should assist to establish the effectiveness of budgeting in the public schools in order to ensure that quality education is promoted and whether parents in SGBs are knowledgeable enough to prepare the budget.

\section{Findings}

Emerging from the findings, it is apparent that an acute contrast of effective budgeting exists in the public schools of Lejeweleputswa District. For instance, thirty-three (33) questionnaires completed by principals in town schools revealed that $100 \%$ of respondents did not experience any problems in drawing school budgets in terms of the provincial department of education (PDoE) guidelines. They also indicated that PDoE funding policy improved their school budget because they received sufficient money to proceed with academic and non-academic programmes smoothly without logistical challenges.

On the other hand, twenty-two (22) questionnaires completed by school principals in township schools revealed that, only 6 schools, which is $27 \%$ were capable of drawing 
school budgets and satisfied with PDoE funding policy because they received sufficient money at the beginning of first term to proceed with academic and non-academic programmes without logistical challenges. They also indicated that the PDoE funding policy is also relevant because allocation of funds is calculated on the basis of the number of learners per school and the poverty level of such schools.

However, 16 (73\%), which is the majority of principals in the township schools indicated that a number of schools experienced serious problems when dealing with budgeting, particularly because of the lack of knowledge from the side of parents. Another challenge of township schools seems to relate to inadequate funding. This became evident as these principals were also dissatisfied about insufficient allocation of funds by PDoE which cater only for learning and teaching support materials (LTSM) and recurrent costs, while excluding some essential items for progressive school functioning. They also revealed that funds were not deposited on time, resulting in taking funds from other school accounts not budgeted for. They further indicated that the Department does not pay for some item/s included in the submitted budgets.

The expressions of SMTs corroborated the findings from the principals. To this end, sixty (60) questionnaires completed by SMTs revealed that general school budget in town schools accommodates all classroom needs because the budget is well planned to cater for all basic needs of their schools, including classroom needs.

While on the other hand, the questionnaires completed by 14 (32\%) SMTs in township schools revealed that general school budgets accommodate all classroom needs because the school budgets were well planned by all stakeholders, and desired basic needs were catered for, including classroom needs. On the contrary, 30 (68\%) SMTs indicated that the general school budgets did not accommodate all classroom needs, because they always experience a shortage of support material, including text books.

In as far as educators are concerned, seventy-one (71) questionnaires completed revealed that, all town schools' budgets express the fundamental objectives of their schools, because they are well planned to cater for all basic needs of the schools; drawn up by all school stakeholders; accommodate learners' needs first and are reasonable; and planned responsibly and honestly.

On the other hand, from 59 questionnaires completed by educators in township schools, 20 (34\%) revealed that the budgets expressed the specific school objectives because of careful planning to cater for all the basic needs of the schools. While $39(66 \%)$ 
Effective Use of Budgeting as a Tool Towards Financial Management in Schools 403

educators indicated that the school budgets did not express the specific school objectives because:

- a shortage of cleaning materials, teaching and learning materials regularly occurred;

- budgets were only approved by individuals such as the school principals and the chairperson of SGBs;

- budgets accommodate the individual needs of SMTs only, especially because they cover the principals' transport costs, private calls, the internet, faxes, birthday parties, SGBs' catering and baking cakes during school holidays; and

- funds are never available for official school functions such as learners' farewells, spring days and school funerals.

With regard to school financial clerks, twenty-nine (29) questionnaires completed in town schools revealed that their financial committees are skilful enough to manage their school funds due to an excellent financial policy operating in their schools, encouraging regular auditing to avoid any type of financial discrepancy to occur. They use receipt books, income statements and computer programmes, such as pastel statements to keep records of the money received at their schools.

From 15 questionnaires completed, 4 (27\%) school financial clerks revealed that the financial committees in township schools are doing well in managing their school funds, justifying their skills and knowledge in dealing with finances by indicating that:

- $\quad$ they had never started the academic year with unpaid debts, applied for overdraft facilities at a bank; and

- there were no financial discrepancies in their schools, due to the excellent book keeping system of financial administrators, good financial planning and adequate budgeting.

On the contrary, 11 (73\%) financial clerks, revealed that the financial committees in township schools are not skilful enough to manage their schools' funds. They revealed that a shortage of support materials towards the middle of the academic year was always experienced, there is disconnection of basic services, and educators fail to attend workshops due to lack of funds. 
Concerning the parents-governors, sixty-two (62) questionnaires completed in town schools, show that parents bear adequate knowledge of the budgeting procedure of their schools, of which, 47 parents, which is (76\%) were skilful and knowledgeable in drawing and compiling budgets because of their careers. On the other hand, from 78 questionnaires completed, 30 (38\%) parents serving in the SGBs of township schools revealed that they are knowledgeable about the process of school budgeting. While 48 (62\%) parents have not adequate knowledge of the process of school budgeting. Furthermore, 58 (74\%) parents revealed that they still need financial training. While 20 (26\%) parents had received intensive financial training from their work places.

\section{Discussion}

The findings in this study, confirm that budgeting is not effective in some schools in South Africa. As shown in the literature, financial management should start with budgeting, which, firstly requires SGBs and SMTs to prioritise the needs of the schools, based on the broad picture of the school's total income. Evidently, the financial plans of some schools do not take into consideration the realities of the needs of the schools, hence they experience shortage during the year.

Again, the apparent lack of knowledge of financial management from the parentsgovernors cannot be ignored. The continuous training of SGBs is critical in order for them to be effective in carrying out financial planning and management. As shown in the literature, lack of financial planning and control results in waste and inefficient management of resources. If SGBs plan and manage school funds efficiently and effectively, catering and baking cakes during school holidays, as revealed, could be avoided.

Furthermore, the approval of budgets by individuals such as principals and the chairpersons of SGBs is the manifestation of misunderstanding of school governance, which on the other hand, shows the violation of policies and poor training. As the literature shows, the approval of budget must be done in a general meeting of parents, where the majority will vote for its approval.

The above discrepancy emphasises the argument of Grant-Lewis and Naidoo (2004) cited in Xaba (2011:208) that SGBs require training to understand legalese, Constitution 
and the SASA, and various provincial policies, as well as departmental regulations and circulars.

Given these discussions, it is evident that the findings in this study provide important insight of the discrepancies that exist pertaining to budgeting and financial management processes in some schools of Lejweleputswa District.

\section{Conclusion and Recommendations}

The responses from the participants in this study show that schools in South Africa, particularly the township schools have not yet turn the corner to effectively plan for the use of resources at their disposal. This emanates from the contradicting findings of the way in which the schools meet their needs. It is clear from the responses of the participants that some schools lack the required competencies related to the broad planning of school activities, which should inform their budgets.

Thus, a need exists for capacity-building in order to turn the tide of township schools, and ensure that quality learning and teaching is prioritised. This could be achieved if SGBs develop the requisite knowledge for prioritising and budgeting. This means that continuous training of SGBs in township schools to ensure proper budgeting and financial management is a must.

Firstly, training should concentrate on financial planning to ensure that school objectives and activities are managed efficiently and effectively to avoid waste and fruitless expenditures, and thereby be able to promote quality education. Secondly, training should be on communication and reporting on school financial performance, as this could assist to build positive attitudes among stakeholders and induce strong confidence in SGBs and SMTs for managing school funds. As shown in the literature, effective communication translates into a "fertile environment" which should assist schools to receive external financial support. Fourthly, knowledge of policies that relates to financial management in schools is fundamental, as this would assist SGBs and SMTs to make democratic decisions that are taken through inclusive participation and the consultation of all stakeholders. Lastly, training would also assist for execution of other functions such as delegating financial tasks, financial organising, financial coordinating, financial leadership and control. 


\section{List of References}

- $\quad$ Best, J.W. \& Kahn, J.V. 2003. Research in education. New York: Congress Cataloguing.

- Bisschoff, T., Du Plessis, P., \& Smith, E. 2004. Effective School Marketing. Pretoria: Van Schailk.

- Blandford, S. 1997. Resource Management in Schools: Effective and Practical Strategies for the Self-Managing School. Trowbridge: Pitman Publishing.

- Botha, N. 2013. Financial Management and Leadership in Schools. Cape Town: Pearson

- Busher, H., Harris, A., \& Wise, C. 2000. Subject Leadership and School Improvement. London: Routledge.

- Bryman, A. \& Gramer, D. 1999. Quantitative Data Analysis with SPSS Releases for Windows: A Guide for Social Scientists. New York: Library of Congress.

- Clark, T.A. \& Lacey, R.A. 1997. Learning by Doing: Panasonic partnership and systemic school reform. Florida: St Lucia press.

- Coleman, P. 1998. Parent, Student and Teacher Collaboration: The Power of Three. California: Corwin Press

- Correia, C., Flynn, D., Uliana, E., \& Wormald, M. 2000. Financial Management. Cape Town: Zebra.

- Gorton, R. \& Alston, J.A. 2009. School Leadership and Administration. Important concepts, case studies, \& simulations. New York:McGraw Hill.

- Daft, R.L. 1995. Understanding Management. London: The Dryden press

- David, M., Bryd, D., \& Mclntyre, J. 1999. Research on Professional Development School: Teacher Education Yearbook VII. California: Sage.

- Dean, J. 2000. Improving Children's Learning. Effective Teaching in The Primary School. New York: Routledge.

- Dodd, A.W. \& Konza, J.L. 2002. How communities build stronger schools. Hampshire: Palgrave MacMillan.

- Esterhuyse, C., \& Horn, D., \& Liebenberg, C. 2005. Dynamic Business Studies. Learner's Book Grade 10. Johannesburg: Kagiso Education. 
- $\quad$ Everard, K.B. \& Morris, G. 1996. Effective School Management. London: Paul Chapman.

- Fidler, B. 1997. 'Strategic Management' Choices for self-managing schools. London: Paul Chapman.

- Frost, D., Durrant, J., Head, M., \& Holden, G. 2000. Teacher-Led School Improvement. New York: Routledge.

- Gallagher, D.R., Bagin, D., \& Kindred, L.W. 1997. The School and Community Relations. New York: Needham Heights.

- Gann, N. 1998. Improving School Governance. How better governors make better schools. Washington: The Falmer Press.

- Gold, A. \& Evans, J. 1998. Reflecting on School Management: Mater Classes in Education series. Philadelphia: Falmer press.

- Harris, J.M. 1996. Financial Skills for Teachers. London: Kogan.

- Herring, R.D. 1997. Multicultural Counselling in Schools: A Synergetic Approach. Alexandria: Library of Congress.

- Horne, H. \& Brown, S. 1997. 500 Tips for School Improvement. London: Kogan.

- Human, J.J., Llewellyn, E.L., Tshabalala, H.S.S., Eksteen, F.R.L.N., \& Miller, H.R. 2005. OBE for FET Business Studies. Grade 10 Learner's Book. Cape Town: Nasou Via Afrika.

- Knight, J. 1995. Professional Skills for Teachers Delegation Skills for Teachers. Philadelphia: Kogan.

- Knight, J. 1997. Strategic Planning School Managers. London: Kogan.

- Latchem, C. \& Hanna D.E. 2001. Leadership for Second Century Learning. Global Perspectives from Educational Innovators. London: Kogan.

- $\quad$ Laws, S., Harper, C., \& Marcus, R. 2003. Research for Development. New Delhi: Sage.

- Levacic, R. 1995. Local Management of Schools Analysis and Practice. Philadelphia: Open University.

- Makhubela, B.S. 2005. The Role of the School Governing Body in Financial Administration at Sokisi Secondary School: A case study. Master's Mini-dissertation. Pretoria: University of Pretoria.

- Mestry, R. \& Bisschoff, T. 2009. Financial School Management Explained (3 ${ }^{\text {rd }}$ ed.). Cape Town: Pearson. 
- Mestry, R. 2013. A critical analysis of legislation on the financial management of public schools: A South African perspective. De Jure, Vol. 46(1). pp: 162 - 177.

- Radebe, N.G. 1995. Teacher and pupil perceptions on the role of Principals in the new educational dispensation in South Africa: Unpublished MEd Dissertation. Pretoria: Vista University.

- Reason, P. \& Bradbury, H. 2001. Handbook of: Action Research: Participative Inquiry and Practice. London: Sage.

- Sallis, E. \& Jones, G. 2002. Knowledge Management in Education. Enhancing Learning and Education. London: Kogan.

- Saye, M.K. 1998. The changing role of the Principal of a public Primary School: A Financial School Management Perspective. Johannesburg: RAU.

- Smith, S.C. \& Piele, P.K. 1997. School Leadership. Handbook for Excellence. London: University of Oregon.

- Starrat, R. 1996. Transforming Educational Administration. New York: McGraw-Hill.

- South Africa. Department of Education. 2002. National Norms and Standards for School Funding: Financial management for schools training Manual 2. Pretoria: Government Printers.

- South Africa. Department of Education. 1996. South African Schools Act (Act No. 17579 of 1996). Cape Town: Government Printers.

- Van der Westhuizen, P.C. 1996. Effective Education Management Impression. Pretoria: Haum.

- Van Schalkwyk, M.J. 1999. Communication for Management and Secretarial Students. Parow: Creda communication.

- Watson, D. 2000. Managing Universities and colleges: Guides to good practice Managing strategy. Philadelphia: Open University.

- Xaba, M. \& Ngubane, D. 2010. Financial accountability at schools: challenges and implications. Journal of Education, No. 50. pp: $139-160$.

- Xaba, M.I. 2011. The possible cause of school governance challenges in South Africa. South African Journal of Education, No. 31. pp: $201-211$. 
Effective Use of Budgeting as a Tool Towards Financial Management in Schools 409

AUTHORS' CONTACT:

\section{MOSALA, George MOFOLO, Malefetsane A.}

Department of Humanities, Department of Mgt. \& Governance

Central University of Technology Walter Sisulu University

Email: mosalageorge1@gmail.com Email:mmofolo@wsu.ac.za 